\title{
1. Unravelling the nexus between entrepreneurship, neighbourhoods and communities - introduction
}

\author{
Reinout Kleinhans, Darja Reuschke, Maarten \\ van Ham, Colin Mason and Stephen Syrett
}

\subsection{ENTREPRENEURSHIP, NEIGHBOURHOODS AND COMMUNITIES}

Until recently, entrepreneurship and neighbourhood studies were separate academic disciplines which rarely interacted with each other. However, recent macroeconomic and societal trends have pointed the spotlight on the nexus between entrepreneurship, neighbourhoods and communities, highlighting not only the importance of 'the local' in entrepreneurship, but also the huge gaps in our knowledge base regarding this tripartite relationship. To date, most research on entrepreneurship, firm formation and innovation, compares entrepreneurial activities, ambitions and policies between countries, or investigates entrepreneurship in a regional context (see e.g. Buckingham et al., 2012; Fritsch and Storey, 2014), largely ignoring the 'local'.

Despite the growing evidence on the importance of the neighbourhood, entrepreneurship studies have rarely 'scaled down' to cities and neighbourhoods including the residential context of where entrepreneurs live. This missing local and social perspective which brings in the social context of entrepreneurs is even more surprising in light of the increasing interest in the role of social networks for entrepreneurship (Somerville and McElwee, 2011; Bailey, 2015) and economic activity more generally. Crucially, most research on the role of networks for firms and start-ups has focused on the location of the firm. It is known, for example, that contacts with (former) colleagues are relevant for starting up a business and those contacts are retained over a distance. However, research on entrepreneurship from a gender perspective suggests that for understanding social networks of entrepreneurs and firm owners, the concept of community is important (Hanson, 2009). 'Community' refers to the valuable connections between 
people including family, friends, and co-members of voluntary associations, which are maintained through social networks (Delanty, 2003). It is common knowledge that communities and neighbourhoods can be interrelated but do not often overlap (Wellman and Leighton, 1979; Chaskin, 1997). Neighbourhoods comprise localised spaces of social interaction often delineated by administrative boundaries, while communities are formed by connections between people with similar interests or social backgrounds and attitudes, which may, or may not, have a clear spatial base. While entrepreneurs may foster local social and economic networks with business partners and others, they may also create communities of practice that extend beyond 'the local' but are not recognised by studies with a regional perspective.

This book investigates the neglected role of community, neighbourhoods and local social networks for entrepreneurship. Many European countries have witnessed decades of urban regeneration policies, which have often been unsuccessful in both economic and social terms, often breaking up and dispersing tightly knit neighbourhoods, and failing to strengthen local opportunities for employment or decrease levels of social isolation. Policymakers across Europe have turned to fostering entrepreneurship in deprived neighbourhoods and communities, for example as a means to bring young people out of unemployment back into work (OECD, 2003; Welter et al., 2008), especially since the great economic crisis of 2007/2008 (Fairlie, 2013). Entrepreneurship is considered a key element in enhancing local economic development through job creation and increased productivity, as well as ensuring greater social inclusion (Williams and Huggins, 2013, 166; see also Blackburn and Ram, 2006; Syrett and North, 2008). Policymakers and researchers have not only been interested in individuals in deprived areas but also in how forms of community-based entrepreneurship may benefit people, places, and more generally, the 'common' good locally (Peredo and Chrisman, 2006; Somerville and McElwee, 2011). Community-based social enterprises may take over the management of formerly state-provided services or facilities (Bailey, 2012), combat poverty (Teasdale, 2010) and sponsor bottom-up regeneration of deprived neighbourhoods either working alongside, in opposition to, or in the absence of state-led regeneration programmes.

Over time, academic disciplines that study entrepreneurship and firm formation have widened to include a variety of social and economic science disciplines. In much of the existing literature, a distinction is drawn between entrepreneurship taking place in neighbourhoods or communities, and entrepreneurship taking place for neighbourhoods and communities. This emphasises the importance of scale (see also Steyaert and Katz, 2004). Many chapters in this volume apply a geographic lens to the links between 
neighbourhood and entrepreneurship, and treat 'community' as a local, spatially embedded concept. Ronald Coase, winner of the 1991 Nobel Prize for economy, has claimed that the relation between entrepreneurship and community is the next true frontier for entrepreneurship research (Coase and Wang, 2011).

Hence, this volume is a response to the international call for interdisciplinary approaches to entrepreneurship and firm formation to overcome entrepreneurship research and neighbourhood and community studies' mutual neglect for one another's fields of research (e.g. Peredo and Chrisman, 2006; Lyons et al., 2012; Daskalaki et al., 2015; Fortunato and Alter, 2015; Reuschke and Houston, 2016). This book aims to shed light on the multiple relationships between entrepreneurship, neighbourhoods and communities across several countries. Chapters explore the importance of the neighbourhood and local social networks for individual entrepreneurs. The concept of community will be explored here through a particular focus upon community-based social enterprises and their relationship with wider economic and political trends.

\subsection{HOW NEIGHBOURHOODS AND COMMUNITIES SHAPE ENTREPRENEURSHIP}

The need to devote more attention to the relationship with neighbourhoods and communities for understanding entrepreneurship lies, paradoxically, in the radical changes of (inter)national and regional labour markets. Labour markets are changing dramatically in advanced economies in response to fundamental and structural economic and technological changes, resulting in the decline of permanent employment and in the growth of freelance and self-employed workers. This change in employment relations is also labelled the 'gig economy'; an economy with a strong prevalence of short-term contracts between independent contractors and organisations (Donovan et al., 2016). The relationship between labour market analysis and entrepreneurship becomes increasingly blurred through the rise in self-employment. While there is considerable debate over what constitutes an entrepreneur, it is evident that entrepreneurs and the self-employed are not synonymous although there is clear overlap between the two and the majority of business owners are self-employed. Self-employment is a heterogeneous category that includes a range of activities from highly professionalised freelancers to disguised employees. The broad set of self-employed workers display varying levels of control and independence within the economic system, which often require different skills, capacities and personality traits to those associated with the entrepreneur. Part 
of the difficulty in academic analysis is because of the greater availability of data on self-employment in comparison to the limited data on entrepreneurs; previous research has often conflated entrepreneurship and self-employment as a matter of convenience rather than in the pursuit of academic rigour.

International statistics highlight the importance of the self-employed workforce. In the United States, there were roughly 17 million independent, self-employed workers; a number which is likely to almost double in the next decade (Tovey, 2013). Across the Atlantic, the United Kingdom had 4.6 million self-employed workers in 2015 (ONS, 2016), which roughly equals an increase of 17 per cent between 2008 and 2014 (D'Arcy and Gardiner, 2014). In both the UK and the Netherlands the recovery after the economic crisis has been largely driven by self-employed workers (Hatfield, 2015). In the Netherlands, this category has almost doubled in size from about 700,000 in the late 1980s to 1.3 million in 2014 (Stam and van de Vrande, this volume). This is partly hidden unemployment; many of these self-employed make very little money.

There is growing evidence that neighbourhood contexts impact on entrepreneurship and self-employment in various ways. Many self-employed workers use their home as workplace - a phenomenon that has started to attract attention from policy and business groups (Mason and Reuschke, 2015; Mason et al., 2011, 2015). This calls into question the resources and conditions that neighbourhoods can provide for (would-be) entrepreneurs, self-employed workers and different types of firms. Bailey $(2015,21)$ has suggested that

We can think of the entrepreneur's neighbourhood both in terms of 'space' (a locational resource) and in terms of 'place' (a social or relational resource). As a locational resource, the neighbourhood can provide land or premises as well as access: to markets or demand; to market knowledge or research; to business services or infrastructure such as broadband; or to image or reputation. As a social or relational resource, the neighbourhood context might be an important influence on attitudes to entrepreneurship as well as shaping the chances of business success. Local networks or social capital can provide resources and support, knowledge and innovation, or opportunities for collaboration.

Studies have shown that the neighbourhood context may influence firm locational choices (Sleutjes and Völker, 2012) and that local networks in neighbourhoods where (would-be) entrepreneurs live are crucial for generating and realising business ideas. Other research has measured the proximity of nascent business to established entrepreneurs' residences (Andersson and Larsson, 2016) and the social capital of business owners (Schutjens and Völker, 2010). Employment studies have found that neighbourhoods 
are crucial for job searches by young people from disadvantaged backgrounds (Tunstall et al., 2012). Although these studies indicate the potential importance of the neighbourhood context (including social capital), in fact, very little is known on whether entrepreneurs actually interact in neighbourhoods and the extent to which they use social resources in the neighbourhood. Earlier studies have also hinted at the importance of role models by showing that "entrepreneurship is self-reinforcing in nature and concentrates geographically because of the social environment as individuals follow societal clues and are influenced by what others have chosen to do' (Williams and Williams, 2012, 676, citing Feldman, 2001 and Minniti, 2005).

However, the relationship between social networks and entrepreneurship is by no means only supportive. Social networks, particularly in dense-knit communities, can prevent efforts to climb up the social ladder. In such cases, downward-levelling social norms are used contra-productively (Portes, 1998) towards entrepreneurship. Deprived neighbourhoods are usually assumed to have high levels of bonding social capital but much less bridging capital (Forrest and Kearns, 2001; Bailey, 2015). The latter form of social capital is highly dependent on social networks that transcend neighbourhoods and connect through (less intimate) social ties to people that can provide access to resources that are helpful for entrepreneurship. In contrast, many entrepreneurs in deprived neighbourhoods who build upon their strong social bonds with other people on low income, are often locked into markets that offer limited opportunities for business development (Blackburn and Ram, 2006; Syrett and North, 2008).

From a neighbourhood perspective, the role of gender is intriguing but has also rendered ambivalent research outcomes. Women appear to have a stronger reliance on local networks to set up a business than men (Hanson, 2009; Hanson and Blake, 2009; Ekinsmyth, 2011). However, other studies comparing women and men could not find gender differences in the use of neighbourhood resources for business purposes (Reuschke and Houston, 2016). Thus, the role of gender is still largely unknown.

In sum, because the relationship between entrepreneurs and their communities is a neglected topic in the entrepreneurship literature (Ratten et al., 2012; Lyons et al., 2012), we know very little about the ways in which neighbourhoods and communities help to create, sustain but also hinder or even destroy entrepreneurship:

Entrepreneurship does not take place in a vacuum, nor is it restricted to relationships between entrepreneurs and their customers, suppliers, investors, partners, and competitors. The actions of entrepreneurs can have both productive (job and wealth creation) and unproductive (e.g. unhealthy competition and environmental degradation) impacts on communities. Similarly, the policies 
and initiatives adopted by communities can be both helpful (e.g. infrastructure provision and maintenance, financial and non-financial programs to assist entrepreneurs) and detrimental (e.g. ill-conceived regulations and well-meaning but poorly designed market interventions) to entrepreneurship. (Lyons et al., 2012, 1)

The neglect of community influences on entrepreneurship and enterprise is partly due to the focus in entrepreneurship and business studies on what makes individual firms successful, rather than what makes communities successful (Lyons et al., 2012; Fortunato and Alter, 2015), and the neglect of firm owners and entrepreneurs in community and neighbourhood studies. According to Fortunato and Alter $(2015,450)$,

the field of entrepreneurship continues to witness a deep transition from thinking about entrepreneurship as an individualistic effort, supported by community actors - toward one that sees entrepreneurship as a socially embedded, community-wide effort where many actors can contribute.

Viewing entrepreneurship as a community-based (instead of individual) effort shifts the focus to how entrepreneurship can influence neighbourhoods and communities, in particular through entrepreneurial actions of residents joining forces.

\subsection{HOW ENTREPRENEURSHIP INFLUENCES NEIGHBOURHOODS AND COMMUNITIES}

Fairly recently entrepreneurship has been connected to the debate on the implications of welfare state regimes, labour market change, and social inclusion. Neoliberalism and welfare state retrenchment have shifted the economies of advanced Western states and are now reshaping the ways in which citizens and the public, private and third sectors interact with each other. In the aftermath of the global economic crisis of 2007/2008, many Western countries have enacted austerity measures and public policy reforms, and simultaneously encouraged what policymakers refer to as 'active citizenship'. In reality this means that citizens are required to take responsibility and actively self-organise to address gaps arising from spending cuts in health care, education, employment and neighbourhood policies (Newman and Tonkens, 2011; Wells, 2011; Bailey and Pill, 2015). Whether this devolution of responsibility will truly enhance people's agency is questionable and needs critical assessment. The general assumption is that active citizenship is most effective when rooted in collective and entrepreneurial actions of groups of residents, because 'voluntary, 
community-based agencies are believed to be better able to meet the needs of their consumers because they reside closer to the people being served and are less bureaucratic than public institutions' (Gilbert, 2004, 114).

A particular form of active citizenship is community-based enterprise, which can take various positions vis-à-vis the market, state and other institutions. First, citizens can take over the management of services or facilities that were previously funded by public authorities, for example libraries, community centres and local swimming pools. This manifestation of active citizenship is perceived as a viable alternative to state-based welfare provision (Mori, 2014).

Second, neighbourhood residents or community members may observe serious deficiencies in a particular area which need to be addressed, but to which other agencies are unlikely to respond. Such deficiencies may range from deprivation, poor health, inadequate housing or a lack of community facilities, inter alia. The fact that neither state nor market institutions properly address these deficiencies can motivate individual residents and groups to join forces and to set up an organisation with the aim to provide community-based solutions (Bailey, 2012, 26-27).

Third, community members may act together based on a shared belief that they can deliver specific goods at lower costs, higher quality and in more environmentally friendly ways than regular state or market providers. Examples are cooperatives developing co-housing, sustainable energy (solar panels, wind turbines), farming, craft produce and elderly care (Mori, 2014; Wagenaar and Van der Heijden, 2015; Bauwens, 2016). In sum, bottom-up, community-based entrepreneurial activities are increasingly seen as solutions for deficiencies in public services and as contemporary bottom-up neighbourhood regeneration efforts.

Entrepreneurship is commonly believed to increase not only the economic strength and innovation of countries, regions and cities, but also of neighbourhoods and communities (OECD, 2003; Baumol et al., 2007). This volume will focus particularly on community enterprises; organisations which are set up and operated by local residents, aiming to invest in their neighbourhood and create benefits through entrepreneurial activities. Community enterprises are often supported by local governments and other institutions, partly because they seek to be inclusive and work for the common good (Peredo and Chrisman, 2006; Somerville and McElwee, 2011; Bailey, 2012). However, there is little empirical and policy-related understanding of community enterprises (Teasdale, 2010; Pierre et al., 2014). Hence, the ways in which entrepreneurship can benefit, shape and transform neighbourhoods, particularly those areas affected by social deprivation and poverty, is an open and timely research question that will be addressed in this book. 


\subsection{CONTENT OF THIS VOLUME}

This book is a collection of chapters discussing interdisciplinary theoretical and empirical insights into the importance of the neighbourhood and localised spaces, the rise and meaning of community-based enterprise, and the role of changing social and business networks and social capital of entrepreneurs in residential neighbourhoods.

The volume is divided into three parts. Part I addresses neighbourhoods as economic places and enterprise cultures, and focuses on how neighbourhoods, localised spaces and localised social networks provide conditions for entrepreneurship and business, based on case studies in the United Kingdom, the United States, France and the Netherlands. Special attention is devoted to how networks of entrepreneurship are embedded in wider societal relations such as gender relations, and how (in particular female) entrepreneurs draw on these networks (social capital) in their entrepreneurial endeavours. This part of the book also analyses innovations regarding contemporary working spaces, especially those of self-employed workers ('solopreneurs').

Part II focuses on the concept of 'community'. The entrepreneurshipcommunity interrelationship will be explored in this part of the book through the concepts of community entrepreneurship, economic democracy and co-production between entrepreneurial citizens and professionals. Community-based (social) enterprise and its potential for contemporary bottom-up neighbourhood regeneration will be investigated in particular in the United Kingdom, the United States, and the Netherlands. The origins of the concept of community-based enterprise and its development are analysed. Part III outlines the conclusions based on all chapters.

In Chapter 2, Nick Williams and Colin Williams provide a conceptual basis for analysing neighbourhoods as economic places and enterprise cultures. They evaluate how exploitation of entrepreneurial opportunities is contingent on barriers, motivations, and human and social capital endowments of individuals within a locality. The authors argue that entrepreneurs in deprived areas face a range of barriers, including low skills, limited financial capacity and bridging social capital, which are usually more acute in deprived areas than in affluent areas. Entrepreneurial activity in deprived urban areas is often small in scale, with individuals entering trades with low entry barriers, finite and highly localised demand. The authors argue against the often used simple opportunity-necessity dichotomy for understanding entrepreneurial motivations. A more nuanced understanding of motivations is required, with entrepreneurs often starting as necessity-based but becoming opportunity-based as the business expands. The authors conclude that deprived areas do not lack entre- 
preneurial activity per se, despite numerous barriers to entrepreneurship. Instead, a 'hidden enterprise culture' makes entrepreneurs in deprived areas more likely to engage in the informal economy.

In Chapter 3, Marianne de Beer and Veronique Schutjens focus on interfirm networks of entrepreneurs in Dutch residential neighbourhoods and, in particular, on the importance of temporal changes in local inter-firm cooperation contacts. The authors have used panel data from two waves of the Dutch Survey of the Social Networks of Entrepreneurs. Contrary to the stance in the literature that inter-firm cooperation is important for small-sized firms, the authors find that local cooperation with other firms is not a common strategy for entrepreneurs in residential neighbourhoods. They found that networks are highly dynamic, loose and temporal in nature. Only a small portion of all cooperation contacts is located in the neighbourhood or municipality in which the entrepreneurs live. De Beer and Schutjens conclude that, if local embedding of entrepreneurs exists, this will occur through private social networks that are not exploited for business purposes.

Chapters 4 and 5 particularly look at how co-working spaces affect the social networks of self-employed workers and the importance of neighbourhood as a working environment. Against the background of an increasing number of 'solopreneurs' (self-employed people without employees), Erik Stam and Vareska van de Vrande explore flexible co-working spaces in the Netherlands (Chapter 4). They analyse the motives and benefits of solopreneurs for using co-working space provided by Seats2Meet. This co-working space offers solopreneurs and other types of workers the opportunity to interact with others, to expand customer networks, to improve current products and services and to improve business skills. Earlier research has pointed out that many self-employed workers are predominantly home-based. However, solopreneurs, especially the higher educated, are more likely to work in a co-working space (temporarily), maybe not in the neighbourhood where they live, but in the same city. Stam and van de Vrande interpret this trend as the rise of the multifunctional city with distinct places to live and work, and not as an increasing importance of residential neighbourhoods for (self-)employment.

Chapter 5 also analyses collaborative spaces of work but here with the objective to explore their potential for innovation. Ignasi Capdevila derives a classification of collaborative spaces based on their openness, collaboration, knowledge sharing and entrepreneurial approach. Fab labs, hackerspaces, makerspaces, co-working spaces and living labs are further explored using empirical material from different countries. Capdevila concludes that the creation of new collaborative spaces facilitates the emergence of new communities and reinforces existing networks. At the 
local level, collaborative spaces of work and innovation can attract distributed talent. Depending on the management of these spaces, they have the potential to foster the engagement of citizens and provide local platforms for social and economic development.

Chapters 6 and 7 contribute to a stronger conceptualisation of gender in the relations between entrepreneurship, neighbourhood and social networks. In Chapter 6, Beate Volker focuses on social networks by revealing gender differences in the creation of forms of social capital (individualversus neighbourhood-level social capital). She also analyses to what extent the networks of male and female entrepreneurs are local and benefit from community-level social capital (such as having a successful business). Volker uses data from the Dutch Survey of the Social Networks of Entrepreneurs, defining 'neighbourhood entrepreneurs' as those people who have their business either in their own home or close to their home. Unlike De Beer and Schutjens (Chapter 3), Volker finds that self-employed workers' neighbourhood contacts are a large and vital part of their network. Women appear to benefit more than men from weak ties (i.e. ties to acquaintances) although they have fewer of these ties than men, who do not need or use these ties for the performance of their businesses.

In Chapter 7 Jenny Lendrum and Sarah Swider explore informal entrepreneurial practices and how these are gendered. They investigate these in a neighbourhood in Detroit, using ethnographic methods. One important finding is that the spaces women occupy and the activities they participate in make them visible as mothers and wives, but not as economic actors. While many private businesses owned by men make their economic activities highly visible in this neighbourhood, women generally work in businesses operating behind closed, locked doors and limited hours of operation, regulating or removing the development of relationships and thus social capital. Another significant implication is that the home, typically considered as private closed space, is often used as a social open space where women not only do unpaid community work but also operate as entrepreneurs and partake in informal paid work.

Part II shifts focus from individual entrepreneurs, self-employed workers and their social or business networks to the level of 'community'. In Chapter 8 Ana María Peredo and James Chrisman provide a conceptual foundation for understanding 'community-based enterprise' (CBE) that addresses social, economic or environmental goals. They define 'CBE' as a community acting corporately as both entrepreneur and enterprise in the pursuit of the common good. CBE is an unconventional form of entrepreneurship in which collective and individual interests are regarded as complementary and which incorporates communal values and the notion of the common good as essential elements of venture creation. The 
chapter draws on rich empirical material which the authors have collated in various studies in the global south, examines the role that collective action, forms of social capital and size play in the creation of CBE, as well as characteristics such as rootedness in available community skills, and multiplicity of goals. Challenges regarding the balancing of individual and collective outcomes, of reconciling social, economic and environmental goals and withstanding the pressures of globalisation are discussed. Peredo and Chrisman conclude that the concept of CBE represents an alternative and promising model for community development, particularly but not exclusively in impoverished communities.

In Chapter 9, Evan Casper-Futterman and James DeFilippis investigate community-based enterprise through the lens of Community Development Corporations (CDCs), which are the most common organisational form of neighbourhood-based enterprises in the United States. CDCs are notfor-profit corporations that build affordable housing, provide social services, conduct job training development, create community facilities and gardens, provide legal services, some community building organising, and many other programmes and activities. In the literature, this type of community development is being scrutinised because of an increasing prevalence of capitalist market-based logics in 'excluded' urban neighbourhoods where CDCs operate. Casper-Futterman and DeFilippis argue that this binary thinking of pro-market versus anti-market logics is insufficiently nuanced. The authors use the case of the Bronx Cooperative Development Initiative (BCDI) to argue that the use of market logics in community development is more complex than the usual neoliberal critique. BCDI is a multi-stakeholder community development initiative that seeks to build community wealth among low- and middle-income residents of the Bronx by enlarging the scope of local economic actors and policy. BCDI's vision is for entrepreneurialism in which the local businesses are embedded in networks that support community organisation. The case study of BCDI shows that it may indeed be possible to construct local political-economic institutions that make use of markets that are accountable to, and operate in the service of, more just cities.

In Chapter 10, David Varady, Reinout Kleinhans and Maarten van Ham compare American Community Development Corporations (CDCs) with Community Enterprises (CEs), their British counterpart. In the context of slow post-crisis economic recovery and austerity policies, this chapter assesses the potential of community entrepreneurship for neighbourhood revitalisation. The authors found that, while CDCs have a relatively successful record in affordable housing production in distressed areas, CDCs are fundamentally limited in terms of reversing processes of community decline. CEs have focused on local non-housing issues and have 
generally not played a central role in neighbourhood revitalisation. Varady, Kleinhans and van Ham conclude that, first, CEs and CDCs are assumed to take on more social responsibility, but their success depends on the ability to secure external funding. Second, CDCs and CEs face trade-offs in the multiple requirements of maintaining financially stable operations, offering needed social services, promoting community economic development and maintaining high environmental standards. Finally, although both CEs and CDCs aim to strengthen community participation, the desired levels of participation and the presumed benefits usually have not been achieved or are of a long-term nature difficult to grasp by research.

In Chapter 11, Nick Bailey focuses on a specific type of Community Enterprises (CEs) - asset-based community development trusts (CDTs) and their contribution to contemporary British urban regeneration. CDTs have evolved since the 1970s, responding to government policies that encouraged the transfer of assets and service delivery from the public sector to third sector bodies. Bailey presents three models in order to outline the key dimensions of CDTs, using a number of examples. The findings show that CDTs are often fully committed to seeking sustainability while operating on the margins of profitability. Only the larger CDTs can make a significant contribution to wider regeneration strategies in urban communities. The author concludes that greater flexibility is needed in transferring assets and integrating CEs in broader regeneration strategies, while acknowledging that CDTs cannot keep up with rapid changes in policies because they are predominantly concerned with achieving their own viability. Hence, 'entrepreneurial' in the context of CDTs means being able to respond quickly to new opportunities arising in relation to funding sources or assets to be acquired.

In Chapter 12, Reinout Kleinhans discusses the emergence of CEs in the Netherlands. The basic concept has been strongly inspired by the British experiences discussed in Chapters 10 and 11. In the context of the Dutch 'Participation Society', citizens are given the responsibility to self-organise and to fill gaps in service provision as a consequence of budget cuts and policy reforms. Especially in deprived neighbourhoods, CEs face huge challenges in the transition from 'subsidy-dependent' reactive resident associations to entrepreneurial CEs with a market-oriented business model. Kleinhans maintains that CEs need to cooperate with various stakeholders who bring in various resources to achieve better outcomes. This form of co-production is investigated using data from repeat interviews with civil servants and housing association staff members. Professionals struggle with the societal reality in which CEs operate, but support the discourse of self-organisation and in particular the importance of cooperation between residents and local governments. This cooperation is fundamental to the 
notion of co-production. However, the ambivalent and contradictory responses of local governments are rather forms of 'counter-production' that keep CEs uncertain over the possibilities to acquire assets, and lacking in crucial information or consent for the development of various activities. This sometimes smothers the motivation of CE initiators and other volunteers, and maintains CEs' full dependence on formal local institutions.

Emiel Rijshouwer and Justus Uitermark provide more insights into Community Enterprises in the Netherlands through a study of former Amsterdam community centres and their transformation into CEs in Chapter 13. Informed by austerity politics and the disillusionment with welfare policies, governments are increasingly looking at civil society as providers of community services. In order to qualify for government funding, community centres are obliged to propagate entrepreneurship and acquire external financial resources to continue their activities. The authors investigate how this ideal concept works out in practice. Drawing upon interviews with representatives of community centres, Rijshouwer and Uitermark find that only one of the studied centres conforms to this ideal. All other centres are durably dependent on formal institutions, not only in financial terms, but also in terms of indispensable professional support for volunteers, a point that is also made by Kleinhans (Chapter 12). The authors conclude that despite the restrictions austerity policies pose to the autonomy of citizens, the enactment of independency and entrepreneurialism is widespread among stakeholders in this field.

Finally, Chapter 14, written by the editors, synthesises findings and arguments across the books and formulates a basis for future research. In summary, the chapters offer a range of interdisciplinary perspectives which investigate the multiple relationships between entrepreneurship, neighbourhoods and communities. Collectively, they contribute to an increase in our knowledge of the nexus between entrepreneurship, neighbourhoods and communities, and in particular the importance of 'the local' for the interrelationships between these entities.

Together, the contributions to this volume attempt to answer several questions. How do neighbourhoods (in particular socio-economically deprived areas) and local social networks provide conditions for entrepreneurship, business and innovation? Specifically, how are networks of entrepreneurship embedded in wider societal relations such as gender relations, and how do (in particular female) entrepreneurs draw on these networks in their entrepreneurial endeavours? What are the implications of new localised co-working spaces for innovation and business development in neighbourhoods? To what extent can community-based enterprises provide services, wealth and benefits for members of these communities? How do policymakers react to these new bottom-up forms of active 
citizenship, in the context of austerity regimes and urban policy reforms? Which opportunities and barriers do community enterprises face in their evolution from small start-ups, towards established social businesses that make a sustainable impact on economic development, community participation and local welfare provision?

Finally, we have identified several directions for future research on the nexus between entrepreneurship, neighbourhoods and communities. First of all, social capital appears to be highly relevant for (individual) entrepreneurship and community enterprises (alongside other forms of capital). Several contributions to this volume endorse the viewpoint that both the 'consumption' and 'production' of social capital are still not well understood. A relevant investigation would be the nature of and balance among different forms of social capital as those are related to region, size and specific character of the community and social networks, and to effectiveness and sustainability. Secondly, current research on communitybased forms of entrepreneurship is of a cross-sectional design and thus not able to identify changes over time. More longitudinal research is needed to understand the relative performance of such collective forms of entrepreneurship and their social, economic and environmental impacts.

\section{ACKNOWLEDGEMENTS}

The work published in this edited volume partly draws on a grant of the UK Economic and Social Research Council (ESRC) to Darja Reuschke, Colin Mason, Stephen Syrett, Maarten van Ham and Duncan Maclennan (Grant No. ES/L001489/1). See also http://www.st-andrews. ac.uk/homebusiness.

\section{REFERENCES}

Andersson, M. and Larsson, J. (2016), 'Local entrepreneurship clusters in cities', Journal of Economic Geography, 16(1), 39-66.

Bailey, N. (2012), 'The role, organisation and contribution of community enterprise to urban regeneration policy in the UK', Progress in Planning, 77(1), 1-35.

Bailey, N. (2015), 'The place of neighbourhood in entrepreneurship: attitudes, resources and sorting', in: C. Mason, D. Reuschke, S. Syrett and M. van Ham (eds), Entrepreneurship in Cities: Neighbourhoods, Households and Homes, Cheltenham, UK and Northampton, MA, USA: Edward Elgar, pp. 19-38.

Bailey, N. and Pill, M. (2015), 'Can the state empower communities through localism? An evaluation of recent approaches to neighbourhood governance in England', Environment and Planning C: Government and Policy, 33(2), 289-304. 
Baumol, W., Litan, R. and Schramm, C. (2007), Good Capitalism, Bad Capitalism, and the Economics of Growth and Prosperity, New Haven, CT: Yale University Press.

Bauwens, T. (2016), 'Explaining the diversity of motivations behind community renewable energy', Energy Policy, 93, 278-290.

Blackburn, R. and Ram, M. (2006), 'Fix or fixation? The contributions and limitations of entrepreneurship and small firms to combating social exclusion', Entrepreneurship and Regional Development, 18(1), 73-89.

Buckingham, H., Pinch, S. and Sunley, P. (2012), 'The enigmatic regional geography of social enterprise in the UK: a conceptual framework and synthesis of the evidence', Area, 44(1), 83-91.

Chaskin, R. (1997), 'Perspectives on neighborhood and community: a review of the literature', The Social Service Review, 71(4), 521-547.

Coase, R. and Wang, N. (2011), 'The industrial structure of production: a research agenda for innovation in an entrepreneurial economy', Entrepreneurship Research Journal, 1(2), 1-12.

D'Arcy, C. and Gardiner, L. (2014), Just the Job - or a Working Compromise? The Changing Nature of Self-Employment in the UK, Resolution Foundation Report, accessed 23 September 2016 at http://resolutionfoundation.org/wp-content/ uploads/2014/05/Just-the-job-or-a-working-compromise-FINAL.pdf.

Daskalaki, M., Hjorth, D. and Mair, J. (2015), 'Are entrepreneurship, communities, and social transformation related?', Journal of Management Inquiry, 24(4), 419-423.

Delanty, G. (2003), Community, London: Routledge.

Donovan, S., Bradley, D. and Shimabukuro, J. (2016), What Does the Gig Economy Mean for Workers?, Washington DC: Congressional Research Service, accessed 23 September 2016 at http://digitalcommons.ilr.cornell.edu/cgi/viewcontent.cgi? article $=2512 \&$ context $=$ key_workplace.

Ekinsmyth, C. (2011), 'Challenging the boundaries of entrepreneurship: the spatialities and practices of UK "Mumpreneurs", Geoforum, 42, 104-114.

Fairlie, R. (2013), 'Entrepreneurship, economic conditions, and the great recession', Journal of Economics \& Management Strategy, 22(2), 207-231.

Feldman, M. (2001), 'The entrepreneurial event revisited: firm formation in a regional context', Industrial and Corporate Change, 10(4), 861-891.

Forrest, R. and Kearns, A. (2001), 'Social cohesion, social capital and the neighbourhood', Urban Studies, 38(12), 2125-2143.

Fortunato, M. and Alter, T. (2015), 'Community entrepreneurship development: an introduction', Community Development, 46(5), $444-455$.

Fritsch, M. and Storey, D. (2014), 'Entrepreneurship in a regional context: historical roots, recent developments and future challenges', Regional Studies, 48(6), 939-954.

Gilbert, N. (2004), Transformation of the Welfare State: The Silent Surrender of Public Responsibility, Oxford: Oxford University Press.

Hanson, S. (2009), 'Changing places through women's entrepreneurship', Economic Geography, 85, 245-267.

Hanson, S. and Blake, M. (2009), 'Gender and entrepreneurial networks', Regional Studies, 43, 135-149.

Hatfield, I. (2015), Self-Employment in Europe, London: Institute for Public Policy Research, accessed 23 September 2016 at http://www.ippr.org/assets/media/ publications/pdf/self-employment-Europe_Jan2015.pdf. 
Lyons, T., Alter, T., Audretsch, D. and Augustine, D. (2012), 'Entrepreneurship and community: the next frontier of entrepreneurship inquiry', Entrepreneurship Research Journal, 2(1), 1-24.

Mason, C. and Reuschke, D. (2015), Home Truths: The True Value of Home-Based Businesses, Glasgow: Federation of Small Businesses Scotland, accessed 23 September 2016 at http://www.fsb.org.uk/policy/rpu/scotland/assets/home $\% 20$ truths $\% 20-\% 20$ final.pdf.

Mason, C., Carter, S. and Tagg, S. (2011), 'Invisible businesses: the characteristics of home-based businesses in the UK', Regional Studies, 45(5), 625-639.

Mason, C., Reuschke, D., Syrett, S. and Ham, M. van (eds) (2015), Entrepreneurship in Cities: Neighbourhoods, Households and Homes, Cheltenham, UK and Northampton, MA, USA: Edward Elgar.

Minniti, M. (2005), 'Entrepreneurship and network externalities', Journal of Economic Behavior and Organization, 57(1), 1-27.

Mori, P. (2014), 'Community and cooperation: the evolution of cooperatives towards new models of citizens' democratic participation in public service provision', Annals of Public and Cooperative Economics, 85(3), 327-352.

Newman, J. and Tonkens, E. (2011), Participation, Responsibility and Choice: Summoning the Active Citizen in Western European Welfare States, Amsterdam: Amsterdam University Press.

OECD (2003), Entrepreneurship and Local Economic Development: Programme and Policy Recommendations, Paris: Organisation for Economic Co-operation and Development Publishing.

Office for National Statistics (ONS) (2016), Trends in Self-Employment in the UK: 2001 to 2015, London: Office for National Statistics, accessed 23 September 2016 at https://www.ons.gov.uk/employmentandlabourmarket/peo pleinwork/employmentandemployeetypes/articles/trendsinselfemploymentin theuk/2001 to2015.

Peredo, A. and Chrisman, J. (2006), 'Toward a theory of community-based enterprise', Academy of Management Review, 31(2), 309-328.

Pierre, A., Von Friedrichs, Y. and Wincent, J. (2014), 'Entrepreneurship in society: a review and definition of community-based entrepreneurship research', in: A. Lundström, C. Zhou, Y. Von Friedrichs, and E. Sundin (eds), Social Entrepreneurship: Leveraging Economic, Political, and Cultural Dimensions, Switzerland: Springer International Publishing, pp. 239-257.

Portes, A. (1998), 'Social capital: its origins and applications in modern sociology', Annual Review of Sociology, 24, 1-24.

Ratten, V., Welpe, I. and Dana, L. (2012), 'Editorial: community-based entrepreneurship - towards a future research agenda', International Journal of Innovation and Regional Development, 2(1-2), 1-3.

Reuschke, D. and Houston, D. (2016), 'The importance of housing and neighbourhood resources for urban microbusinesses', European Planning Studies, 24(6), 1216-1235.

Schutjens, V. and Völker, B. (2010), 'Space and social capital: the degree of locality in entrepreneurs' contacts and its consequences for firm success', European Planning Studies, 18(6), 941-963.

Sleutjes, B. and Völker, B. (2012), 'The role of the neighbourhood for firm relocation', Tijdschrift voor Economische en Sociale Geografie, 103(2), 240-249.

Somerville, P. and McElwee, G. (2011), 'Situating community enterprise: a theoretical exploration', Entrepreneurship \& Regional Development, 23(5-6), 317-330. 
Stam, E. and Vrande, V. van de (2017), 'Solopreneurs and the rise of co-working in the Netherlands', this volume.

Steyaert, C. and Katz, J. (2004), 'Reclaiming the space of entrepreneurship in society: geographical, discursive and social dimensions', Entrepreneurship \& Regional Development, 16(3), 179-196.

Syrett, S. and North, D. (2008), Renewing Neighbourhoods: Work, Enterprise and Governance, Bristol: Policy Press.

Teasdale, S. (2010), 'How can social enterprise address disadvantage? Evidence from an inner city community', Journal of Nonprofit \& Public Sector Marketing, 22(2), 89-107.

Tovey, A. (2013), 'Freelancers are buoying recovery in UK firms', Daily Telegraph, 21 November 2013, accessed 23 September 2016 at http://www.telegraph.co.uk/ finance/jobs/10464171/Freelancers-are-buoying-recovery-in-UK-businesses. html.

Tunstall, R., Lupton, R., Green, A., Watmough, H. and Bates, K. (2012), Disadvantaged Young People Looking for Work: A Job in Itself?, York: Joseph Rowntree Foundation, accessed 23 September 2016 at http://www.jrf.org.uk/ sites/files/jrf/young-people-disadvantage-jobseekers-full.pdf.

Wagenaar, H. and Heijden, J. van der (2015), 'The promise of democracy? Civic enterprise, localism and the transformation of democratic capitalism', in: S. Davoudi and A. Madanipour (eds), Reconsidering Localism, London: Routledge, pp. 126-145.

Wellman, B. and Leighton, B. (1979), 'Networks, neighborhoods, and communities: approaches to the study of the community question', Urban Affairs Review, 14(3), 363-390.

Wells, P. (2011), 'Prospects for a big society? Special issue of people, place and policy', People, Place and Policy Online, 5(2), 50-54.

Welter, F., Trettin, L. and Neumann, U. (2008), 'Fostering entrepreneurship in distressed urban neighbourhoods', International Entrepreneurship and Management Journal, 4(2), 109-128.

Williams, N. and Huggins, R. (2013), 'Supporting entrepreneurship in deprived communities: a vision too far?', Journal of Small Business and Enterprise Development, 20(1), 165-180.

Williams, N. and Williams, C.C. (2012), 'Evaluating the socio-spatial contingency of entrepreneurial motivations: a case study of English deprived urban neighbourhoods', Entrepreneurship \& Regional Development, 24(7-8), 661-684. 
Reinout Kleinhans, Darja Reuschke, Maarten van Ham, Colin Mason, and Stephen Syrett - 9781785367243 Downloaded from PubFactory at 04/26/2023 01:23:57PM 